\title{
Review of the Archaeology of Mobility: Old World and New World Nomadism
}

\author{
Diane Gifford-Gonzalez
}

Published online: 11 March 2010

(C) The Author(s) 2010. This article is published with open access at Springerlink.com

Some of us researching pastoralism in Africa have felt that despite divergent paths to food production in the Americas, the Southwest Asian archaeological sequence often still serves as a universal template against which the African evidence is measured, thereby constraining interpretations (Gifford-Gonzalez 2005; Neumann 2005). It is, therefore, refreshing to see Near Easternists and other Eurasianists interrogate the received wisdom on the emergence and nature of pastoralism in their own research areas. This thought-provoking anthology results from a symposium at the 2004 Society for American Archaeology meetings and the Fourth Advanced Seminar of UCLA's Cotsen Institute. It exemplifies the institute's goal of stimulating interchange between anthropological archaeologists and archaeologists working in text-aided traditions.

The editors assert that much can be gained by comparing hunter-gatherer and pastoralist mobility strategies, even arguing that these typologies must be qualified in light of ethnographic and archaeological evidence. Three chapters focus on hunter-gatherers, 21 on herding peoples, and one on both past and present and range from archaeological field studies to ethnoarchaeology to textual analyses. The challenges of a "multiregional and multidisciplinary" engagement are reflected in the editors' introductory negotiation of the word "nomadism," nearly extinct as an unmodified noun in anthropological archaeology but alive and well in Near Eastern and Eurasian studies, with prehistoric archaeology's more commonly used "mobility."

Such a dialog can risk mutual incomprehension, but it also has the power to reveal the implicit assumptions and categories of each field, opening new research avenues. The interdisciplinary challenge thus enables a more reflexive approach, which is sustained to varying degrees through the chapters. Text-aided archaeologists often critique "the desert and the sown" dichotomy and other canonical aspects of their fields. Many propound a more dynamic, landscape-scale view of site function and

D. Gifford-Gonzalez $(\bowtie)$

University of California, Santa Cruz, CA, USA

e-mail: dianegg@ucsc.edu 
mobility that sets them apart from the earlier, big-site excavation strategies of their fields.

A short review cannot describe all the paths traveled by The Archaeology of Mobility's 26 contributors. I choose here to touch on chapters that especially struck me as an Africanist concerned with pastoralists.

Alison Betts carefully reviews existing models for emergence of pastoralism in the Near East with evidence from the Levantine border of the North Arabian steppe. This indicates that "marginal" PPNB people there kept caprines, farmed, hunted, and foraged, creating diverse sites in different habitats. Betts questions the traditional Southwest Asian stipulation of a necessary interdependence of pastoralists with farmers, as this does not hold for at least one early case there. Africanists who have grappled with traditional notions of food production in Saharo-Sahelian cases will find this of interest.

Reinhard Bernbeck's “An archaeology of multisited communities" brings refreshing reflexivity to canonical Near Eastern archaeological notions of the "nomad," targeting misapplication of direct historical analogies, dichotomous typologies, and uncritical use of textual evidence. Trained in Near Eastern archaeology, Bernbeck fruitfully applies Anglophone prehistoric archaeology perspectives in his study. He proposes a dynamic model to account for archaeological evidence of South Anatolian pastoral nomads including creation and cyclical use of permanent structures (the latter also attested by Abbas Alizadeh for southern highland Iran). Like Binford (1982) did with regard to hunter-gatherer sites, Bernbeck argues that some locations can change function over time, contributing to complex records of human habitation.

Steven Rosen presents a longue durée narrative of eight millennia of pastoralist life in the Negev and adjacent regions, in which climate, technological innovations, and state interventions interacted to produce changing lifeways and archaeological signatures. As in earlier works, Rosen rejects pastoral nomadism as an evolutionary stage. Like Bernbeck, he questions the uncritical use of analogies with historic pastoral groups, contending that some Levantine pastoral production and mobility strategies have no modern analogs. Rosen's use of the phrase "herder-gathers," for the sixth millennium BCE pastoralists in the Negev, and his discussion of their associated megalithic solstice monuments, should pique the interest of Saharanists.

Africanist Andrew Smith documents how the Khoekhoen of South Africa's Cape region, profusely documented historically, are "virtually invisible" in the archaeological record, despite surveys targeted to known Khoe camps. This sobering view of pastoral invisibility is tempered by Smith's thoughtful assessment of factors producing it, which can inspire assessment of similar cases. These include the relation of high mobility to the species herded and a region's primary productivity, as well as the scant discard record of metal-using herders. Smith reviews evidence for the earliest southern African sheepherders, arguing that Khoisan peoples along the Zambezi and in the Caprivi Strip adopted animals from northern pastoralists. While admitting that parts of his narrative are open to debate, Smith posits a testable scenario that, in the absence of archaeological evidence, may be evaluated using animal and human genetics, as well as linguistic evidence.

Jelmer Eerkens, a California and Great Basin archaeologist studying the 700$1,000 \mathrm{BP}$ record of sedentary to highly mobile hunter-gatherers, presents "five 
conflicts or problems that hinder the use of pottery among mobile societies" and thoughtfully assesses his archaeological evidence with these. Africanists working in the Sahara-Sahel may not agree that their evidence supports each of Eerkens' points, but his work is relevant precisely because it provokes a more systematic assessment of the role of early Holocene (9800-8000 BP) Saharan pottery and of latter ceramics associated with mobile pastoralists.

In a sophisticated discussion of pastoralist mobility and reasoned argument against typological approaches, Michael Frachetti contends that variability is in fact the hallmark of pastoralists. This stems from their flexible and virtually instantaneous responses to changing ecological, economic, political, and even ideological circumstances. Frachetti advocates a cultural landscape approach to research on "dynamic pastoral landscapes," exemplifying this with a case study from the Koksu Valley in the Dzhungar Mountains of Khazkhstan.

Africanist Stuart Smith uses a broad range of theory to explore the EgyptianNubian colonial interface at Askut and Tombos. He cites textual evidence that ethnicity as a social construct was strategically deployed by the Pharaonic Egyptian state and is not simply a post-medieval European invention. Smith's analysis of Askut household ceramics illustrates the value of looking below surface appearances. Despite the Egyptian architecture, Askut pottery, especially cooking wares, show a pervasive Nubian signature, which wanes and waxes with Egyptian state power but always endures. Smith invokes studies of gender in the archaeology of European colonialism to explore the pervasive Nubian influence in household lifeways and cooking.

Willeke Wendrich presents a functional inventory of contemporary Sudanese Ababda household and traveling gear, providing insights into the multitude of tasks accomplished by highly curated artifacts, mainly of perishable materials, and places these in the context of gendered labor. The chapters, and the book's cover photo by an Ababda man of his family, evoke the unique worlds of modern mobile pastoralists.

The late Roger Cribb was among only a few researchers with direct field experience with both sedentarizing pastoralists and hunter-gatherers forced to settle. Comparing Turkish pastoralists and Australian aboriginal people, he notes how sedentarization blocked their fundamental conflict resolution tactic, moving away from antagonists. Cribb argues that pastoralists used tents as template for a built environment that inhibited occasions of conflict. He predicts residential configurations in space that may typify sedentarizing hunter-gatherers or pastoralists, which would repay assessment with other archaeological and ethnographic data.

This anthology offers many chapters to engage Africanists interested in mobile foragers, pastoralists, or people of mixed strategies. Some offerings fulfill the volume's multidisciplinary goals more than others, but this is a commendable effort to bridge several disciplinary divides, one which often succeeds in challenging and informing the reader.

Open Access This article is distributed under the terms of the Creative Commons Attribution Noncommercial License which permits any noncommercial use, distribution, and reproduction in any medium, provided the original author(s) and source are credited. 


\section{References}

Binford, L. R. (1982). The archaeology of place. Journal of Anthropological Archaeology, 1, 5-31.

Gifford-Gonzalez, D. (2005). Pastoralism and its consequences. In A. B. Stahl (Ed.), African Archaeology (pp. 187-224). London: Blackwell.

Neumann, K. (2005). The romance of farming: plant cultivation and domestication in Africa. In A. B. Stahl (Ed.), African Archaeology (pp. 249-275). London: Blackwell. 